\title{
Designing gender-equalizing parental leave schemes - What can we learn from recent empirical evidence from Europe?
}

\author{
Eine geschlechtergerechte Ausgestaltung von Elternzeitpolitik in Europa \\ - was können wir aus den jüngsten empirischen Befunden aus \\ verschiedenen europäischen Ländern lernen?
}

\begin{abstract}
:
This article conducts a systematic review exploring the link between parental leave policies and the gender division of labour. The reviewed material encompasses quantitative empirical articles that study the effect of a variation in leave policies on mothers' integration into the labour market and on fathers' engagement in family work. The analysis focuses on studies that were (i) conducted between January 2000 and May 2014, (ii) conducted in European countries, (iii) published in peer-reviewed journals and (iv) written in English or German. The analysis suggests that there are several aspects of parental leave that seem to be especially relevant in designing genderequalizing parental leave schemes. With regard to the effects of leave on mothers' employment, it seems crucial that the duration of leave and payments provided is of a moderate length. With regard to the effects of leave on fathers' engagement in family work, it seems most important to provide leave that is explicitly reserved for fathers. In addition, studies consistently find that leave policies affect women very differently with regard to their levels of education and income.
\end{abstract}

Key words: parental leave, gender equality, women's labour force participation, fatherhood, domestic division of labour

\begin{abstract}
Zusammenfassung:
Der Beitrag erarbeitet eine systematische Literaturanalyse jener empirisch-quantitativen Literatur, die sich mit dem Einfluss von Elternzeit auf eine ausgeglichene Arbeitsaufteilung zwischen Frauen und Männern beschäftigt. Dabei werden jene Studien untersucht, welche 1. Daten aus Europa heranziehen, 2. zwischen Januar 2000 und Mai 2014 durchgeführt, 3. in referierten Zeitschriften publiziert und 4. auf Englisch oder Deutsch verfasst wurden. Die Analyse des Materials erlaubt es, jene Merkmale eines Elternzeitmodells zu identifizieren, welche besonders relevant für eine gleiche Arbeitsaufteilung zwischen Männern und Frauen sind. Erstens ist die Bereitstellung einer mittleren Dauer von Elternzeit besonders wichtig, um die Integration von Frauen auf den Erwerbsarbeitsmarkt zu fördern. Zweitens hat besonders die Einführung eines Elternzeitanspruchs alleine für Väter eine positive Auswirkung auf deren Beteiligung im Bereich der unbezahlten Familienarbeit. Des Weiteren zeigen die Ergebnisse, dass sich der Effekt von Elternzeit auf Frauen in der Erwerbsarbeit je nach dem Bildungs- und Einkommensniveau unterschiedlich gestalten kann.
\end{abstract}

Schlagwörter: Elternzeit, Elterngeld, Gleichstellung der Geschlechter, Erwerbstätigkeit der Mütter, Väterbeteiligung an der Familienarbeit, Arbeitsaufteilung zwischen den Geschlechtern 


\section{Introduction}

There has been increasing political interest in parental leave policies as instruments for the implementation of gender equality in society. On a national level, several countries have shifted from a long low-paid parental leave model that offers no incentives for fathers' leave taking to policies of moderate duration that are well-paid and explicitly reserve some leave time for fathers. On a European level, a recent directive from 2010 (Council Directive 2010/18/EU) explicitly acknowledges that family policies should contribute to the achievement of gender equality and entitle both parents to at least four months of parental leave, with the supplement that this leave entitlement should - in principle - be provided on a non-transferable basis.

This policy debate is also reflected in scholarly publications in social science. Several publications reflect on the nature of an ideal parental leave policy that would best support gender equality in the division of labour. Gornick and Meyers (2008) suggest a genderequalizing leave policy providing an individual and non-transferable right to six months of leave for both parents that should be paid at a rate of 100 per cent of previous earnings. Parents should be allowed to combine leave with part-time employment and to draw down their six-month entitlement incrementally, over several years. Haas (2003) suggests that, in addition to an individual and non-transferable right for mothers and fathers, substantial pay and flexibility, leave rights should be actively promoted with substantial educational campaigns. Gheaus and Robeyns (2011) suggest a model with four weeks of maternity leave and, by default, five months of parental leave for each parent. Their proposition suggests giving both parents access to an online parental leave registry system, where they can change the default setting. They argue that, by making use of the behavioural and normative power of default by giving paid leave to fathers, the traditional gender division can be challenged.

I would like to contribute to this debate by shedding more light on the empirical literature that studies the effects of parental leave policies on the gender division of work. There is a large strand of literature that empirically studies the effects of leave policies on maternal employment and fathers' involvement in unpaid work. This body of literature is growing fast. It encompasses studies with various methodological approaches, and exploits different sources of data for different countries and time periods. It looks at the effects of different aspects of leave policy schemes, such as the duration of leave, the provision of payments or the eligibility criteria. It studies different outcomes, such as mothers' working hours or wages and fathers' leave take-up rates or hours spent on household work. However, to the author's knowledge, there is no article that systematically reviews this body of literature in order to summarize the most salient results and discuss them with regard to the implications that can be drawn for the implementation of parental leave policies that support gender equality in the division of labour. This essay builds on other review articles that give an overview of the literature on the determinants of mothers' employment (Hegewisch/Gornick 2011; Steiber/Haas 2012) or on the impact of parental leave policies on various outcome variables (Galtry/Callister 2005).

In my analysis, "gender equality in the division of labour" is understood as a scenario, where, on average, men and women contribute equally to both the sphere of employment and family work. This concept has prominently been referred to as the "universal caregiver model" by Fraser (1997) and "the dual-earner/dual-carer model" by Crompton (1999) 
and Gornick and Meyers (2003). Given the actual distribution of workload, a "contribution towards gender equality in the division of labour" would increase either the share of men's investment in family work or the share of women's engagement in employment.

Clearly, it is a wider range of social policy measures that will be crucial in determining the gender division of work, and such measures differ across countries and over time (see e.g. Pfau-Effinger 2001). Gornick and Meyers (2003) stress that, besides leave policies, there are in particular two other crucial policy areas that have to be adapted in order to get closer to an earner/carer society. There should be working-time measures that increase parents' options for engaging in high-quality reduced-hour work, complemented by child-based entitlements to early childhood education and care provided through multiple venues, to give parents a broad choice of arrangements, mainly paid for by the government. However, the focus of this article will lie with the interrelation between leave policies and the gender division of work.

\section{Parental leave policies in European countries}

Typically, there are three elements that make up a set of parental leave policies: maternity leave, paternity leave and parental leave. Following Moss (2014), they can be described as follows. The first element, maternity leave, denotes an employment-protected leave of absence for mothers around the time of childbirth. This type of leave is generally understood as a health and welfare measure, intended to protect the health of mother and child. As can be seen from Table 1, practically all European countries provide maternity leave regulation, varying between a few months in countries such as Austria, Germany and Lithuania and 12 months in the UK, mostly covered by earning replacement rates of between 60 and 100 per cent of previous income. The second element, paternity leave, denotes an employment-protected leave of absence for fathers after childbirth. This type of leave aims to enable fathers to spend time with their family around the time of childbirth. Paternity leave is only offered in some countries, ranging between one day in Italy and thirteen weeks in Slovenia, and often features an income replacement rate similar to that applied to maternity leave. The third element, parental leave, denotes an employmentprotected leave of absence for employed parents - mothers or fathers - often following maternity or paternity leave periods. This type of leave aims to enable parents to care for their young children. Parental leave regulations vary widely across European countries between no leave in Switzerland at all and three years in, for instance, Poland, Estonia and Germany. Many countries provide payments during parental leave, either in the form of a generous income replacement payment or in the form of a less generous flat-rate benefit. There are several options for explicitly building the policy objective of gender sharing into parental leave regulations. Most prominently, a "fathers" quota" that reserves some portion of leave for the father can be implemented as a measure to increase their leave taking. For instance, in Sweden, 60 days out of the duration of paid parental leave are reserved for each parent and cannot be transferred. Other countries, such as Germany, Italy and Portugal, provide bonus months of paid leave that are only for fathers.

The general use of the term "parental leave" in the literature, however, is ambiguous sometimes denoting an actual parental leave regulation in a narrow sense, sometimes ap- 
plied as an umbrella term subsuming all three types of leave. As can be seen in Table 1, some countries, such as Iceland, Norway and Sweden, do not necessarily distinguish between maternity, paternity and parental leaves, referring only to "birth leave", part of which is for mothers, part for fathers, and part for parents to divide as they choose. In this article, the term "parental leave", or simply "leave", is used as an umbrella term and will refer to the sum of all of these types of leave, including maternity, paternity and parental leave (in a narrow sense). Furthermore, this article will distinguish between "total leave", denoting the total duration of leave, whether paid or unpaid, and "paid leave", denoting only that leave period that is supplemented financially.

The channels through which leave might affect the gender division of work are diverse. The provision of extensive durations of maternity leave, such as are available in Ireland, Poland and the UK, may perpetuate the role of mothers as primary caregivers as these entitlements are typically reserved for mothers and not accessible to fathers. The provision of long paternity leave periods, such as those in Slovenia and Finland, clearly supports the involvement of fathers. However, it is not clear to what extent as they are usually used in parallel to maternity leave, implying that fathers are not taking the role of primary carer during that time. Still, paternity leave periods might deepen the relationship between father and child in the first few weeks and therefore positively influence their likelihood of leave take-up and childcare involvement later on. The ways in which parental leave might influence the gender division of work largely depend on the specific characteristics of a leave model. First of all, leave policies that are too short, such as in Switzerland, might have detrimental effects on mothers' labour market participation as they might not allow mothers sufficient time to take care of their new-born babies, provoking them to opt out of the labour market completely. On the other hand, parental leave that is very long, such as that in Poland or Spain, might give mothers incentives to withdraw from the labour market for overly long periods. Leave durations that are combined with reasonable high payments are likely to prevent economic dependency of mothers on their partners during leave and provide incentives to fathers to take leave. Similarly, leave entitlements that are not transferable to the partner have the potential to raise fathers' involvement in childcare. In addition, there are several other - more detailed - characteristics that might be important for fathers' involvement in childcare, such as that (i) leave is provided in a flexible manner, (ii) it allows the combination of part-time work and leave, (iii) it might be taken in several blocks over several years and (iv) the leave entitlement for fathers is not dependable on the eligibility of the mothers. However, flexibility measures might, as well, have the unintended consequence of perpetuating the traditional division of work if these measures are only used by mothers.

\section{Systematic review}

This critical literature review focuses on the effects of parental leave policies on the gender division of labour based on the method of systematic reviewing. A systematic review consists of a review of the research literature using systematic and explicit accountable methods (Gough et al. 2012: 5). A systematic search was conducted in academic research databases with the keywords "parental leave", "maternity leave" or "paternity leave" in combination 
with at least one of the following keywords in the title, abstract or keywords list: fathers, fatherhood, motherhood, take-up, labour market, labour supply, mothers, labour force participation, wages, female employment, female labour supply, male employment, male labour supply, employment pattern, working mothers, working fathers, gender, gender gap, gender equality, division of labour, housework and childcare. The academic databases included ECON Lit, the Social Sciences Citation Index (Web of Knowledge), IDEAS and the International Bibliography of the Social Sciences. The systematic search was further limited to articles that (i) were published after the millennium - encompassing contributions between January 2000 and May 2014, (ii) focus on the study of European countries, (iii) were published in a peer-reviewed journal and (iv) were written in either English or German. Based on the screening of title and abstract of the remaining articles, those contributions that did not conduct a quantitative empirical study were excluded from the article corpus (also excluded were those studies that provided "only" descriptive results and did not provide information on causal relations or statistical associations). The final article corpus generated by the systematic search as specified above contains nineteen contributions on the effect of parental leave on mothers' employment and ten articles on the effect of parental leave on fathers' family work. In addition, it contains three articles that looks into the effects of leave on mothers' family work and fathers' employment.

Notably, the search strategy did not cover many other articles that might contribute to a better understanding of the interrelation between parental leave policies and the gender division of labour. First, as the review focuses on post-millennium publications - encompassing contributions between January 2000 and May 2014 - seminal studies on the matter, such as that by Christopher Ruhm (1998), are not included in the literature discussion. Second, the search strategy focused on papers published in peer-reviewed journals and therefore I do not consider other relevant contributions published in books or as discussion papers, such as Grunow (2013) who focuses on the importance of considering the association between norms and behaviour when it comes to the assessment of men's family work or Cools (2011) who studies the effect of a paternity leave reform in Norway on children's and parents' outcomes. Third, the search criteria excluded those contributions that did not conduct an explorative quantitative study, such as Sullivan et al. (2009) who relate father-friendly policies to fathers' time spent on family work, Leibetseder (2013) who studies the determinants of leave take-up under five different benefit options in Austria, and Pfau-Effinger (2004) whose work points to the cultural and social context in which parental leave policies are embedded.

\section{Literature on the effects of parental leave policies on mothers' employment}

As can be seen from Table 2, fourteen out of nineteen contributions considered in the systematic review have been published on this topic since January 2010. Typically, several different outcome variables are analysed, such as the return to work after leave, mothers' employment participation, weekly working hours, gross wages, occupational segregation and job-related training. Within this body of literature, there is a strong focus on crosscountry studies and the evaluation of policy reforms in Germany. 


\subsection{Studying the total duration of leave}

Most contributions that study a variation in the duration of total leave are conducted on a micro level. Two of these studies use retrospective life course data in order to study the effect of changes in the total duration of leave over time and/or across countries. These data sets are especially useful as they provide information on the complete employment histories of mothers, allowing the study of long-term effects. Brugiavini et al. (2013) study the effects of the duration of total maternity leave on the weeks of work "in job" (i.e. keeping the same occupation) and "out of job" (i.e. exiting the labour force) in 11 European countries. They find that the duration of total leave increases the weeks of work "in job" within completed employment histories, suggesting that mothers take advantage of the maternity leave that is offered to them, while it decreases the weeks of work "out of job", leading to a higher overall labour force participation in the long-run. Similarly, Drasch (2012) studies the effects of four leave reforms in West Germany since 1986 on the return-to-work behaviour of women of different levels of education. She finds evidence of an educational polarization of return-to-work behaviour since 1992, showing that less educated women re-enter the labour market more slowly than women with a university degree. Although it is not possible to disentangle general time trends from the effect of the policy, these results suggest that leave reforms since then have contributed to increasing inequalities of labour market opporsetunities for women with different levels of education. In addition, her findings further support the evidence on the relevance of leave policies for return to work in general, especially with regard to the total duration of leave compared to the duration of payments. The return to work is significantly lower on average across the entire leave period than around the expiration of the leave period.

There are two more micro-level studies on the total duration of leave mainly using panel data for Germany. Grunow, Aisenbrey and Evertsson (2011) study the effects of a variation in leave policies on the return to work of mothers born in the 1950s, 1960s and 1970s, for Germany, Sweden and the United States. They use several dummy variables to indicate different durations of leave over time in these three countries. These vary from variables indicating shorter leave durations in the 1970s and moderate durations in the 1980s to longer leave durations in the 1990s. Their results indicate that extended leave durations delay return to work in all three countries. Similarly, Puhani and Sonderhof (2011) study the effects of a variation in the duration of total parental leave entitlements on the incidence of job-related training, using three different survey data sets for Germany between 1988 and 2000. Within this time span, the German parental leave scheme was extended at several rates, between twelve months of leave in 1986 and 36 months of leave in 1995. In general, they find an increase in job-related training amongst several groups of the population. However, their results indicate that the increase in training incidence between 1988 and 1994 amongst various groups was the smallest for young women. Furthermore, their results show tentative evidence that the extension of leave has not only an impeding effect on the increase of job-related training for all women, but for women without children as well. Some caution must be exercised when deriving conclusions about the potential effects of leave on employer-arranged training as only one of the three survey data sets that are used in the study distinguishes between training that is employerarranged and training based on the worker's initiative. 
Taking a micro-macro perspective, several studies exploit variation in women's employment outcomes in order to estimate equations on their wages, labour market participation or employment hours. In a second step, these studies focus on the coefficient derived by these estimations referring to the effect of having children on these outcomes. The authors relate this coefficient to the respective parental leave policy of a country. The results of these studies are more of a descriptive nature as the second step comprises bivariate analyses or OLS models with only a few data points. One of these studies, De Henau, Meulders and O'Dorchai (2010), looks at the effects of a variation in the duration of total leave entitlements on a "child gap" in women's employment participation. The authors find that the duration of leave is slightly negatively correlated with the child gap, which can be interpreted as an indication that the duration of leave might further increase the gap between the full-time employment participation rates of mothers and nonmothers. Pettit and Hook (2005) focus on a slightly different outcome variable, the "child penalty" in employment participation, indicating the extent to which the negative effect on mothers' employment participation rates (compared to non-mothers) can be explained by the presence of children. They discover non-linearity in the effect of parental leave on employment of women with young children: Their results suggest that the negative relation between having young children and employment is weaker in countries that provide longer durations of leave. However, this association declines with longer leave durations, indicating that the negative relationship between children and employment is smallest in countries with about three years of leave.

In a similar vein, Misra, Budig and Boeckmann (2011) find that the duration of paid maternity leave and the duration of total leave available in a country are associated with a lower child penalty for both employment hours and wages. Furthermore, they find evidence of an inverted U-shaped relation between the duration of total parental leave and the child penalty, with the child penalty on working hours and wages being minimized at around 80 to 100 weeks of leave. Erhel and Guergoat-Larivière (2013) exploit the technique of multi-level modelling and find a lower probability of being in employment for mothers of children below the age of three in countries with longer durations of leave compared to countries with shorter leave.

On a macro level, Genre, Salvador and Lamo (2010) exploit variation in leave policies across time and countries. They find a positive effect on women's employment participation with diminishing returns, again, indicating an inverted U-shaped relationship between leave length and employment participation. According to their estimates, the positive effect on employment is maximized at about eight to nine months of leave. However, in general, the results of macro-level studies have to be interpreted with caution as they are based on aggregate indicators and there are several intervening factors that may also account for the variation in employment outcomes. In addition, the variation in leave policies is sometimes not explained in as much detail as is necessary in order to understand the precise stimulus for a reform, for example in the study by Genre et al., where it is not clear whether they consider the duration of either total or paid leave. In general, the most important finding of the contributions that study a variation in the duration of total leave is that there is a positive inverted U-shaped effect from the duration of leave on employment participation of mothers. 


\subsection{Studying the duration of paid leave}

On a micro level, there are three studies that evaluate the reform of a paid leave scheme in a particular country with regard to the effects on the labour market outcomes of mothers. These studies exploit a change in the leave regulation within the setting of a natural experiment, analysing the effect of the reform on mothers' return-to-work behaviour or subsequent wages. This kind of study design is strong when it comes to the assessment of effects, as it provides a quasi-experiment comparing the outcomes of mothers shortly before (control group) and after (treatment group) a reform. Lalive and Zweimüller (2009) study the effects of a variation in paid leave on several employment outcomes of mothers. In July 1990, the Austrian parental leave scheme was extended from one to two years of leave, in both cases paid at the same low flat rate. Their results depict different effects of the reform in the short run (within three years after a birth) and in the long run (within ten years after a birth). They find that the reform extending leave substantially delays the return to work of mothers, with this negative effect especially pronounced in the short run. They explain this finding by the renewal period of leave. In Austria, leave can be renewed within a certain period without the need to fulfil the eligibility criteria for leave entitlements again. Under short parental leave policies, this renewal period is difficult to achieve for mothers who are planning a subsequent child. Therefore, women return to work very early, but only temporarily, so as to be eligible for another leave entitlement. However, under the long parental leave scheme, the renewal period of leave is easier to achieve. Therefore, mothers planning a subsequent child do not have to return to employment in the short run. This might be an explanation for the strong short-run dynamics, whereas in the long run employment stays practically the same. Furthermore, the authors find a small negative effect of the reform on employment and earnings in the short run, but no significant effect in the long run.

Joseph, Pailhé, Recotillet and Solaz (2013) study the effects of a French parental leave reform in 2004 that introduced six months of paid parental leave subsequent to maternity leave for mothers having their first child. The authors distinguish between fulltime leave takers and part-time leave takers and compare them with "similar" mothers who gave birth to their first child before 2004 and therefore had no access to paid parental leave. For full-time leave takers, their results indicate that the reform had no effect on their later employment participation or wages. This indicates that taking short leave has no negative effect on female labour market outcomes. For part-time leave takers, they find a positive effect from the reform on being in employment 12 and 18 months after birth, indicating that part-time work is favourable for mothers' integration into the labour market after giving birth, allowing them to maintain a link with the labour force. Just as in Lalive and Zweimüller (2009), they find this positive effect on employment participation from part-time leave to be effective only within the first two years after the mother gives birth, and no long-run effects can be derived. At the same time, they find negative effects on subsequent wages for part-time leave takers. The authors suggest that the main reason for these lower earnings could be attributed to the fact that these mothers continue to work part-time after the period of paid leave has ended.

Bergemann and Riphahn (2011) study the effects of a German policy reform in 2007 that introduced a new scheme of shorter, but more generous, parental leave payments. The new benefit amounts to two-thirds of the pre-birth income and is paid for twelve months for 
one of the parents, while an extra two months are available if both parents share the leave. The new transfer replaces a less generous leave payment of a maximum of 300 euros per month, means-tested at the household level, for 24 months. The total parental leave duration of three years remained unchanged by the reform. The outcome variables are based on survey questions about the intention to (i) return to work (ever) and (ii) make a fast return to work (within one year of giving birth). The authors find no significant effect from the introduction of the reform in 2007 on the intention to ever return to work. However, they find a clearly positive effect of the reform on a fast return to work, indicating that short and wellpaid leave seems to speed up return to work compared to longer low-paid leave. They find a higher propensity to return quickly to the labour force among well-educated women and among those woman with a strong attachment to the labour force.

There are three other contributions based on a micro level that study the 2007 parental leave reform in Germany. Geyer, Haan, Spieß and Wrohlich (2013) evaluate the reform within a microsimulation approach using panel data between 2005 and 2008. For the first year after giving birth, they find negative effects on mothers' employment probability from the reform. This effect is most pronounced for mothers with high incomes. However, for the second year after giving birth, they find positive effects on mothers' employment probability, especially for mothers taking up part-time work and mothers with low incomes. Kluve and Tamm (2013) find no evidence of an effect on the intention to return to work in the long run from the 2007 reform. In addition, they confirm the results of Geyer et al. (2013), finding a negative effect on mothers' employment participation within the first year after birth and a positive effect on their likelihood of working one and a half years after giving birth.

Another group of contributions on the micro level investigates the effects of changes in leave law on mothers' return-to-work behaviour by estimating hazard rate models. Although this design is probably not as strong as a quasi-experimental setting with regard to the establishment of causality between leave reforms and labour market outcomes, it provides a reasonable study design for the investigation of effects. For instance, Ronsen and Sundström (2002) study return-to-work behaviour of mothers in Sweden, Finland and Norway. For mothers having their first child, the results suggest that longer durations of paid leave delay the return to work. For Norway and Finland, however, this negative effect is only significant for mothers returning to full-time jobs.

Similarly, Ondrich, Spiess, Yang and Wagner (2003) study several leave reforms in Germany between 1985 and 1991. Within their study period, leave was extended several times, between six months in 1985 and 18 months in 1991. They use three different outcome variables to measure return-to-work behaviour, referring to the return to work (i) within the maternity leave period, (ii) within the parental leave period and (iii) within a post-parental-leave period (six months after the end of parental leave). Their results indicate a negative effect of the extension of parental leave on full-time return to work within the maternity leave period. To study the effect of the amount of pay provided, they capture the variation in parental leave payments using the ratio of monthly parental leave benefits to the monthly net earnings of the mother. They find a negative effect of the benefit-wage ratio on the return to full-time and part-time work during the parental leave period. This indicates that, the higher the earnings replacement provided by the benefit, the longer is the delay in returning to work. 
Lapuerta, Baizán and González (2011) study the effects of a variation in the amounts of parental leave payments on mothers' return to work using administrative data for Spain from 2006. In Spain, there are big variations in payments across regions. Whereas some regions, such as the Basque country, Navarra and Castilla-La Mancha, provide parental leave payments of between 200 and 560 euros per month, others do not provide any payments. Their results indicate that the provision of payments delays mothers' return to work.

On a macro level, Akgunduz and Plantenga (2012) study the effects of variations in the duration of paid leave on women's employment using aggregated macro-level data for 16 European countries from 1970 to 2010 . They find that, at first, longer leave durations positively affect women's employment participation. However, this effect diminishes with the duration of the leave, producing an inverted U-shaped relation between leave length and female employment participation. Their data analysis indicates an optimal leave length, where employment is maximized at 28 weeks of leave. With respect to the effect on working hours, the duration of leave exhibits a positive effect. However, these positive effects from the duration of leave on employment participation and working hours seem to come at a cost, as the authors find a negative effect of the duration of leave on wages, but only for highly skilled women. Looking at the effect on occupational segregation, they find that the share of women working as professionals, legislators, senior officials or managers is slightly negatively influenced by the duration of leave.

In general however, the most important finding of the contributions that study a variation in the duration of paid leave is that the provision of paid leave is a strong determinant of the return to work of mothers. It is an extension of paid leave that delays mothers return to work and the shortening of paid leave periods speeds up return to work.

\subsection{Studying the eligibility for leave}

Taking a micro-macro approach, Pronzato (2009) studies the variation in the eligibility for leave entitlements on mothers' return to work using data for ten European countries between 1994 and 2001. There are two variables that capture the eligibility for leave across women: (i) a dummy variable indicating whether a woman is eligible for leave and (ii) a dummy variable indicting whether a woman is eligible to receive payments during leave. She finds a positive effect of the eligibility for leave in the second or the third year after giving birth on mothers' return to work. Therefore, women who have not returned to the labour market within the first year of giving birth, and who are still eligible for leave in the following two years, are more likely to start working again as compared to those mothers who are not eligible for leave. Furthermore, she finds a negative effect from the eligibility for leave payments on return to work, but only for the first year after giving birth. Analysing the results according to different levels of education, she finds that the positive effect from the eligibility for leave is especially pronounced for medium and highly educated women, whereas the negative effect from the eligibility for payments is strongest for women with little education.

For mothers having their first child, the results of Ronsen and Sundström (2002) suggest a strong positive effect of the entitlement to leave on mothers' return to work in all countries, with the sole exception of mothers returning to part-time work in Finland. 


\section{Literature on the effects of parental leave policies on fathers' family work}

Similarly to the case of the literature studying the effect of leave on mothers' employment, most studies analysing the effect of leave on fathers' family work are from recent years. As can be seen from Table 3, eight out of ten contributions have been published since January 2010. Most contributions analyse the effects of the introduction of a fathers' quota (i.e. leave months that are reserved for fathers), a variation in the duration of total leave, the amount of leave payments or eligibility criteria for leave. Typically, outcome variables measure fathers' leave take-up and their engagement in family work (including childcare) or household work (excluding childcare). There is a regional focus on the Scandinavian countries and Germany.

\subsection{Studying the introduction of a fathers' quota}

One of the most prominent instruments analysed within the literature on the determinants of fathers' family work is the fathers' quota. Several studies analyse this policy element within the setting of a natural experiment. Duvander and Johansson (2012) study the effects of the introduction of two fathers' quotas in Sweden. In 1995, a reform introduced a one-month fathers' quota, leaving the overall duration of paid parental leave the same at 15 months. At the same time, the replacement rate of the benefit paid for the first twelve months was decreased from 90 to 80 per cent, except for the first month of leave used by each parent. In 2002, another reform introduced a second month of fathers' quota, but this time the additional month was added on top of the overall duration of paid leave that - by then - amounted to 16 months. Duvander and Johansson compare the means of parental leave days taken by fathers and find that both reforms substantially increased fathers' leave days. Furthermore, they test whether the effects of the reforms are statistically significant and find this to be the case for both reforms. The introduction of the one-month fathers' quota significantly raised the likelihood of fathers taking leave of more than 30 days, but not of taking more than five weeks. Similarly, the introduction of the second month of fathers' quota significantly raised the likelihood of fathers' taking leave of more than 60 days, but not of taking more than nine weeks.

In a similar vein, Ekberg, Eriksson and Friebel (2013) study the effects of the Swedish fathers' quota from 1995. Their findings suggest that the reform increased fathers' use of leave by about 15 days, with pronounced seasonal peaks in fathers' leave take-up around summer and Christmas, patterns that were further reinforced by the 1995 reform. Interestingly, they also find a change in the take-up behaviour of women, suggesting that they used more of the flat-rate paid parental leave days after the reform. In addition, they study the effect of the reform on the share of sick leave taken by fathers. Fathers that were subject to the new parental leave law, however, did not take a larger share of sick leave than other fathers.

In another study from Norway, Kotsadam and Finseraas (2011) analyse the effect of a fathers' quota on male performance of household work. In 1993, a fathers' quota of four weeks of paid leave was introduced, added to the overall duration for both parents. The results indicate that the respondents shared the task of doing the laundry more equally af- 
ter the introduction of the fathers' quota. With respect to the results on the division of cleaning, there seems to have been a positive effect on male involvement. The authors find no significant effects on the division of cooking tasks.

\subsection{Studying the total duration of leave}

Within the literature on the determinants of fathers' family work, there are four micromacro studies that focus on the effects of a variation in the duration of total parental leave entitlements on fathers' family work. Most of these studies exploit a multi-level modelling approach, assuming that the countries under investigation are as if randomly drawn from an underlying population of all countries. However, as Brian and Jenkins (2015) point out, users of multi-level modelling techniques require 25 countries for linear models and 30 countries for logit models at the very minimum. As Hook $(2006 ; 2010)$ does not fulfil this requirement, the interpretation of these results should be done with caution, as country-level fixed parameters are likely to be estimated imprecisely. The same critique applies to the approach of Erhel and Guergoat-Larivière (2013) for their study about mothers' employment participation, discussed above.

Hook (2006) uses time-use surveys and policy data on a national level from 20 predominantly European countries between 1965 and 2003. The variable indicating the duration of leave refers to the weeks of total leave available in a country. Fathers' family work is measured in minutes per day and is defined by (i) core household work, such as cleaning or cooking, (ii) non-routine housework, such as gardening or shopping, and (iii) childcare. Her results suggest that in countries with a longer duration of leave fathers engage less in family work. Hook (2006) studies the effects on fathers' family work including childcare tasks, Hook (2010) concentrates on their performance of time-inflexible household tasks, excluding childcare. The results suggest that the duration of total leave is associated with a small reduction in fathers' cooking time and with a rise in mothers' cooking time, suggesting that long leave entitlements reinforce the gendered division of cooking. The results show no substantial, significant effects on the sharing of housework. In contrast, the findings by Fuwa and Cohen (2007) suggest that the duration of total leave has an equalizing effect on the division of household work.

Boll et al. (2014) use the same source of time-use data as Hook to analyse the effect of the duration of leave on fathers' childcare time. In their parental leave measure, they distinguish between the number of leave weeks available for fathers that are transferable to their partners and those that are explicitly reserved for fathers. They find a positive association between these measures and fathers' childcare time. They further disentangle these results by the fathers' level of education and show that, whereas the positive association between the number of transferable weeks and paternal childcare is mainly driven by less educated fathers, the relationship between non-transferable leave weeks and paternal childcare can mainly be attributed to highly educated fathers. 


\subsection{Studying the duration of paid leave}

There are three studies on a micro level that study the effects of a variation in paid parental leave entitlements on fathers' take-up. Pull and Vogt (2010) analyse the impact of the German policy reform in 2007 that introduced a new scheme of shorter, but more generous, parental leave payments. Notably, a crucial element of the reform was not only that the new benefit was income-related, but also that paid parental leave was extended for two months if both parents shared the leave. The authors find that the probability of fathers' leave taking increases with the introduction of the reform. However, the results also indicate that the probability of fathers using more than two months of leave drops after the introduction of the reform, and so does the average duration of leave taken by them. As they use a survey that is not representative for Germany, it is not reliable to generalize these results.

These results are further supported by Schober's (2014) study of the effects of two leave reforms in Germany in 1992 and 2007 on mothers' and fathers' weekday hours spent on housework and childcare. She finds evidence that the reform of 1992 that extended the total duration of leave (flat-rate payments) from 18 (18) to 36 (24) months slightly decreased the time fathers spent on childcare. She finds a positive effect, however, of the 2007 reform (see details of the reform above) on fathers' childcare. She finds little evidence of changes in housework activities after either reform.

Similarly, Lapuerta et al. (2011) find a positive effect from the provision of payments on fathers' leave take-up. However, there are no significant effects from the provision of payments on the duration of leave taken by fathers.

Boll et al. (2014), the only study on a micro-macro level addressing this issue, find a positive association between higher levels of leave benefits and paternal childcare. Higher benefits (compared to none) are associated with an increase of almost one hour per week in paternal childcare time, with this relationship being strongest for highly educated fathers.

\subsection{Studying the eligibility for leave}

With regard to the effects of a variation in the entitlement to take leave on fathers' leave take-up, the results of Hook $(2006 ; 2010)$ suggest that, in countries where men are eligible for leave, they do more family work, whereas women do less cooking.

\subsection{Studying the introduction of a gender equality bonus}

There is one study that provides insights into the effect of another measure aimed to increase fathers' parental leave take-up. Duvander and Johansson (2012) analyse the effect of the introduction of a "gender equality bonus" on fathers' leave take-up using administrative data for Sweden between 1995 and 2008 (for details of the study, see above). A reform in 2008 introduced a "gender equality bonus", which is a tax credit that is granted to mothers for each day that the parents share leave more equally. The authors find no significant effect of the introduction of the gender equality bonus on fathers' leave take-up. 


\section{Literature on the effects of parental leave policies on mothers' family work or fathers' employment}

As can be seen in table 4, only few studies look at the effects of leave policies on mothers' family work or fathers' employment. One rare exception is Schober (2014) studying the effect of two parental leave reforms in Germany from 1992 and 2007 on domestic work and childcare of fathers and mothers. Differing from the effects on fathers' childcare, the study finds no significant effect of the leave reforms on mothers' domestic work time or childcare. Rege and Solli (2013) study the introduction of a one month father's quota from 1993 in Norway on fathers' long-term earnings. Their findings strongly suggest that four weeks of parental leave taken by fathers during the child's first year decreases fathers' future earnings. The authors argue that this can be interpreted as suggestive evidence that parental leave use of fathers increases their involvement in the long run. Analysing the labour market effects of the 1995 introduction of a one month father's quota in Sweden, Ekberg et al. (2013) find no substantial effects on fathers' labour market outcomes in the post-reform cohorts.

\section{Discussion}

Very significantly, recent studies support the well-known claim that the duration of leave positively affects women's employment, but in a non-linear way. In addition, the positive effects of the duration of leave on employment participation and working hours seem to come at a cost, as the duration of leave has negative consequences for wages, occupational segregation and job-related training for young women. This further supports the claim that leave should be limited to a moderate duration in order to avoid negative consequences for women in the labour market. How long, though, is a "moderate duration" of leave? With respect to this question, evidence is mixed, and it is not possible to draw conclusions about the optimal duration of leave. Whereas some studies find the positive effect to be maximized at around six to eight months (Genre et al. 2010; Akgunduz/Plantenga 2012), others suggest an ideal duration of eighteen months (Misra et al. 2011) or even around three years (Pettit/Hook 2005). Therefore, it is very difficult to draw general conclusions about the ideal length of leave entitlement. With respect to the duration of paid leave, the literature suggests that a long duration delays mothers' return to work. On the other hand, it has been shown that the provision of parental leave payments positively affects fathers' take-up of leave. Thus, again, there might be some moderate duration of paid parental leave that best supports an equal gender division of labour.

Lalive and Zweimüller (2009) illustrate that the dynamics behind the effects of leave variations on mothers' employment might depend on the time horizon studied. Whereas, in the short run, they find substantial negative effects on employment outcomes from an extension of paid leave in Austria, they find no substantial effects in the long run. Similarly, Geyer et al. (2013) and Bergemann and Riphahn (2011) provide tentative evidence on this matter showing that the introduction of a shorter, but higher-paid parental leave benefit in Germany significantly raised the return to work in the short run, but not in the long 
run. What does this imply? Here, it would be interesting to know more about the compositional background of these groups that did or did not return to work. Is it mainly welleducated mothers who return to work in the short run and mainly mothers with little education who do not change their return-to-work behaviour in the long run?

Additionally, it seems important to distinguish between mothers who return part-time and those who return full-time to work. Geyer et al. (2013) show the positive effect of the "Elterngeld" reform on mothers' employment probability in the second year after giving birth to have been most pronounced for mothers returning part-time. Similarly, Joseph et al. (2013) find a positive effect from the French reform in 2004 on being in employment 12 and 18 months after birth, however, only for part-time leave takers. These findings point towards a complementary relation between leave policies and part-time work. Only a few countries, such as Austria, Finland and Norway, provide leave entitlements combined with a right to work part-time after returning from leave (Moss, 2014, pp. 26ff). However, although the combination of leave with a right to do part-time work might encourage mothers to return to work earlier or even "at all", this measure is still problematic as long as it is only used by mothers. A right to work part-time might, as well, require a fathers' quote to make sure that both mothers and fathers work part-time in order to take better care of their children.

Studies consistently find that leave policies affect women very differently. It seems important to distinguish between women with different levels of education and income. For instance, Drasch (2012) finds evidence of an educational polarization of return-to-work behaviour since 1992, showing that less educated women re-enter the labour market more slowly than women with university degrees. She suggests that leave reforms since then have contributed to increasing inequalities in labour market opportunities for women with different levels of education. Akgunduz and Plantenga (2012) find a negative effect of leave duration on wages, but only for highly skilled women. Here, we need more research on the effects that leave schemes have on mothers' employment with respect to different levels of education.

The recent empirical literature on the effects of parental leave policies on fathers' family work provides several insights, as well. First, the possibilities for studying the effect of a fathers' quota on fathers in a quasi-experimental setting are quite limited as only a few countries explicitly provide incentives for fathers. There are three reforms that have been studied extensively, namely the introduction of a fathers' quota in Norway in 1993, in Sweden in 1995 and 2002, and in Germany in 2007, and the results suggest that a fathers' quota is a promising tool for raising fathers' taking of leave. Can we expect, though, the same implications of a parental leave scheme for the gender division of labour across all European countries, regardless of the welfare-state context and related traditions? Here, it would be interesting to study the effect of a fathers' quota for other countries, such as Portugal, that have a somewhat different welfare-state setting. However, in sum, the evaluations of the fathers' quota point in a promising direction, and an ideal leave model that best supports gender equality should certainly include such a policy element, probably even in a more radical way as currently implemented in European countries, reserving half of the leave period for fathers, as suggested by Gornick and Meyers (2008), Haas (2003) or Gheaus and Robeyns (2011).

In addition, the literature indicates that the positive effect of fathers' quotas on male leave take-up is mainly limited to the months that are explicitly reserved for the fathers. One possible interpretation is that instruments explicitly assigning a certain share of leave 
to fathers may be perceived as some kind of norm for fathers' leave taking. There is some sociological and social policy literature suggesting that family policies often have normative elements. For instance, Neyer and Andersson (2008) argue that family policies in general always reflect the norms that they are intended to create, maintain, or strengthen; these policies signal which kind of behaviour is expected or at least supported; they therefore also extend their impact through their normative or symbolic function. This claim is certainly supported by the reviewed material and, therefore, it seems to be even more important to further extend the leave periods that are reserved for fathers, thereby explicitly encouraging them to take longer leave.

Similarly with regard to mothers' employment participation, the duration of leave entitlements might, as well, set a norm in suggesting that mothers are supposed to stay at home with their children for a certain amount of time. However, what does this imply for countries where the durations of paid leave and job protection are different? Does this suggest the prevalence of two different norms, probably even with respect to different levels of education?

In addition, the findings of Schober (2014) indicate that the German leave reform in 2007 increased paternal childcare time, but had no effect on their involvement in housework. This raises a question that is still poorly answered: What do fathers actually do if they take leave? Does the mere take-up of leave automatically increase their involvement in childcare and housework? If so, what kind of household tasks do men take over from women? Can we really assume that fathers who take a few weeks of leave are significantly more involved in unpaid work in the long run? The findings produced by Ekberg et al. (2013) suggest we should apply some caution in making this assumption, given that fathers who were subject to a leave reform that introduced a fathers' quota did not take a larger share of sick leave in the long run than other fathers. On the other hand, as Rege and Solli (2013) suggest for Norway, the four weeks of parental leave taken by fathers during the child's first year decreases fathers' future earnings, which can be interpreted as suggestive evidence that parental leave use of fathers increases their involvement in the long run. However, there is no evidence about the effects of fathers' leave taking on the long run involvement of fathers in other countries apart from Norway and Sweden.

Several studies find fathers' eligibility for leave to have a positive effect on their involvement in unpaid work. Clearly, fathers' access to leave is one of the preconditions for greater gender equality in the division of work. However, there are some countries, such as Hungary, that offer not only long periods of maternity leave, but also parental leave until the first birthday of the child that is reserved solely for mothers. In general, however, there is a tendency towards parental leave schemes that guarantee certain numbers of months of entitlement for each parent in a non-transferable manner, such as those in Sweden, Iceland and Portugal. Such policies replace the "old system" where leave was divided into a maternity, paternity and parental leave period, clearly benefiting gender equality by granting equal access to leave for both parents.

Although the implementation of a Swedish-style gender equality bonus has been discussed in some countries, such as Austria, the article by Duvander and Johansson (2012) discourages its use as a means to strengthen fathers' engagement in family work, as they find no effect from this bonus. 
Several conclusions can be drawn from the reviewed material with regard to blind spots in the literature. Most characteristics that were considered important for the design of leave policies based on the recommendations of Gornick and Meyers (2008) and Haas (2003) have been well studied in the empirical literature, except for one. It is not possible to draw any conclusions about the effects of flexibility on leave. There is only one study that sheds some light on this question. Ronsen and Sundström (2002) show that mothers mostly return to work just after their leave entitlement has expired but, while this dynamic is pronounced in Norway and Finland, Swedish mothers deviate from these patterns of returning to work. The authors explain this finding by a specific aspect of the Swedish parental leave scheme that is very flexible and encourages mothers to resume part-time work while still on leave or to take leave in several portions instead of one block. Except for this study, there is not a single study that explicitly studies the effect of a variation in flexibility measures on maternal employment or paternal family work. This might be for a good reason. As Moss (2014) suggests, "flexibility" in leave schemes takes a number of forms including, for instance, the possibility (i) to take leave in one continuous block or several shorter blocks, (ii) to take leave on a full-time or part-time basis, (iii) to take longer periods of low-paid leave or shorter periods with higher benefits, and (iv) to take leave together with the other parent at the same time. Therefore, "flexibility" in leave taking is a multidimensional variable that encompasses many different elements and is difficult to operationalize.

Furthermore, Ekberg et al. (2013) find that the introduction of a fathers' quota in Sweden and Norway increased mothers' use of flat-rate paid parental leave days. This raises the question of unintended consequences for mothers' employment stemming from father-targeted measures. It might be that, although father-targeted instruments are successful in raising fathers' take-up, they do not necessarily lead mothers to hand over one of their leave months to their partner in order to return earlier to the labour market.

In addition, this critical review suggests that it might be interesting to go beyond the study of classical instruments, such as duration of leave, payments or the fathers' quota. For instance, the study by Lalive and Zweimüller (2009) sheds light on the possible impact of a renewal period of leave entitlements on mothers' employment. What do we know, though, about the effects of such renewal periods that have been implemented in several countries as a measure to raise fertility?

Finally, especially as leave policies become more and more complex, literature studying the effects of leave needs to be very careful in operationalizing leave. First, it should be clear what kind of leave entitlements are being considered when referring to "leave". As became clear in Section 2 of this article, the general use of the term "parental leave" in the literature is ambiguous. Is it only maternity leave that is considered or does the leave duration considered encompass all types of leave? Is it post-natal leave or is the duration of maternity leave taken before the birth considered as well? Second, it should be clear whether a measure refers to the duration of total leave, i.e. the duration of the job protection period, including paid and unpaid months, or only the duration of paid leave. Meanwhile, in studying leave entitlement that is explicitly reserved for fathers, is this an entitlement taken in parallel to the mother's, such as paternity leave, or is it leave the father uses alone? These kinds of details matter when interpreting the results. 


\section{Conclusion}

When it comes to designing gender-egalitarian parental leave schemes, what conclusions can we draw from this body of literature? First, the total duration of leave should be moderate in order to support mothers' employment in the labour market, as this is where the positive effect of leave on mothers' employment participation is maximized and where the negative effect of long leave periods on other employment outcomes is mitigated. Second, the same applies for the duration of paid leave, which seems to best support gender equality in the division of labour if provided for a moderate length of time. However, the reasoning behind this argument is different, as the provision of very short durations of paid leave discourage fathers from taking any leave, whereas very long durations of paid leave encourage mothers to withdraw from the labour market for very long periods of time. However, neither for the duration of the total, nor for the duration of paid leave is the literature consistent about the exact number of months that is supposed to be "moderate" and therefore maximizes the positive effect on gender equality in the division of labour. Third, there is strong evidence that the provision of a fathers' quota is crucial when designing gender-equalizing leave schemes. This leads to the conclusion that an "ideal" model that best supports gender equality should reserve a considerable share of leave explicitly for fathers. Fourth, in designing gender-equalizing leave schemes, it seems important to differentiate between the effects of leave for different subgroups of women, based on their education or income and whether they return to work part-time or full-time. Finally, this critical review shows that we know very little about the effects of other leave components on the gender division of labour, such as flexibility in leave taking or renewal periods of leave.

\section{Acknowledgement}

This article was developed during a DOC-team fellowship of the Austrian Academy of Science, where I was affiliated to the Vienna Institute for Advanced Studies. I thank U1rike Schneider, Nadia Steiber und three anonymous reviewers for their helpful comments.

\section{References}

Akgunduz, Y. E., \& Plantenga, J. (2012). Labour market effects of parental leave in Europe. Cambridge Journal of Economics, 23. doi: 10.1093/cje/bes052.

Bergemann, A., \& Riphahn, R. T. (2011). Female labour supply and parental leave benefits -The causal effect of paying higher transfers for a shorter period of time. Applied Economics Letters, 18, 1-3, pp. $17-20$.

Boll, C., Leppin, J., \& Reich, N. (2014). Paternal childcare and parental leave policies: Evidence from industrialized countries. Review of Economics of the Household, 12, 1, pp. 129-158.

Brugiavini, A., Pasini, G., \& Trevisan, E. (2013). The direct impact of maternity benefits on leave taking: Evidence from complete fertility histories. Advances in Life Course Research, 18, 1, pp. 46-67.

Cools, S., J. Fiva, and L. Kirkebøen (2011). Causal effects of paternity leave on children and parents. Oslo: Statistics Norway (Discussion Papers No. 657).

Crompton, R. (1999) Discussion and Conclusion. In: R. Crompton, R, (Ed.), Restructuring gender relations and employment: The decline of the male breadwinner. Oxford: Oxford University Press, pp. 201-214. 
De Henau, J., Meulders, D., \& O'Dorchai, S. (2010). Maybe baby: Comparing partnered women's emplyoment and child policies in the EU-15. Feminist Economics, 16, 1, pp. 43-77.

Drasch, K. (2013). Educational attainment and family related employment interruptions in Germany: Do changing institutional settings matter? European Sociological Review, 29, 5, pp. 981-995.

Duvander, A.-Z., \& Johansson, M. (2012). What are the effects of reforms promoting fathers' parental leave use? Journal of European Social Policy, 22, pp. 319-330.

Ekberg, J., Eriksson, R., \& Friebel, G. (2013). Parental leave - A policy evaluation of the Swedish "daddy-month" reform. Journal of Public Economics, 97, 1, pp. 131-143.

Erhel, C. \& Guergoat-Larivière, M. (2013). Labor market regimes, family policies, and women's behavior in the EU. Feminist Economics, 19, 4, pp. 76-109.

Fraser, N. (1997) After the family wage: A post industrial thought experiment In: Fraser, N. (Ed.) Justice interruptus: Critical reflections on the "postsocialist" condition. London: Routledge.

Fuwa, M., \& Cohen, P. N. (2007). Housework and social policy. Social Science Research, 36, 2, pp. 512-530.

Galtry, J., \& Callister, P. (2005). Assessing the optimal length of parental leave for child and parental well-being. Journal of Family Issues, 26, pp. 219-246.

Genre, V., Salvador, R. G., \& Lamo, A. (2010). European women: Why do(n't) they work? Applied Economics, 42, 12, pp. 1499-1514.

Geyer, J., Haan, P., Spieß, C. K. \& Wrohlich, K. (2013). Elterngeld und seine Wirkungen auf das Haushaltseinkommen junger Familien und die Erwerbstätigkeit von Müttern. Zeitschrift für Familienforschung/Journal of Family Research, 25, 2, pp. 193-211.

Gheaus, A., \& Robeyns, I. (2011). Equality-promoting parental leave. Journal of Social Philosophy, 42, 2, pp. 173-191.

Gough, D., Oliver, S., \& Thomas, J. (2012). An introduction to systematic reviews. London: Sage.

Gornick, J. C., \& Meyers, M. K. (2008). Creating gender egalitarian societies: An agenda for reform. Politics \& Society, 36, 3, pp. 313-349.

Grunow, D., Aisenbrey, S., \& Evertsson, M. (2011). Motherhood, family policy, education, and careers in Germany, the US, and Sweden. Kölner Zeitschrift für Soziologie und Sozialpsychologie, 63, 3, pp. 395-430.

Grunow, D. (2013). Aufteilung von Erwerbs-, Haus- und Familienarbeit in Partnerschaften im Beziehungsverlauf. Der Einfluss von Sozialpolitik in Europa. In: Detlev Lück, D. \& Cornelißen, W. (Eds.), Geschlechterunterschiede und Geschlechterunterscheidungen in Europa. Stuttgart: Lucius \& Lucius, pp. 231-257.

Haas, L. (2003). Parental leave and gender equality: Lessons from the European Union. Review of Policy Research, 20, 1, pp. 89-114.

Hegewisch, A., \& Gornick, J. C. (2011). The impact of work-family policies on women's employment: a review of research from OECD countries. Community, Work \& Family, 14, pp. 119-138.

Hook, J. L. (2006). Care in context: Men's unpaid work in 20 countries, 1965-2003. American Sociological Review, 71, pp. 639-660.

Hook, J. L. (2010). Gender inequality in the welfare state: Sex segregation in housework, 1965-2003. American Journal of Sociology, 115, 5, pp. 1480-1523.

Joseph, O., Pailhé A., Recotillet, I. \& Solaz, A. (2013). The economic impact of taking short parental leave: Evaluation of a French reform. Labour Economics, 25, pp. 63-75.

Kluve, J., \& Tamm, M. (2013). Parental leave regulations, mothers' labor force attachment and fathers' childcare involvement: Evidence from a natural experiment. Journal of Population Economics, 26, 3, pp. 983-1005.

Kotsadam, A., \& Finseraas, H. (2011). The state intervenes in the battle of the sexes: Causal effects of paternity leave. Social Science Research, 40, 6, pp. 1611-1622.

Lalive, R., \& Zweimüller, J. (2009). How does parental leave affect fertility and return to work? Evidence from two natural experiments. Quarterly Journal of Economics, 124, pp. 1363-1402.

Lapuerta, I., Baizán, P., \& González, M. (2011). Individual and institutional constraints: analysis of parental leave use and duration in Spain. Population Research and Policy Review, 30, 2, pp. 185-210.

Leibetseder, B. (2013). Parental leave benefit in Austria: Stratified take-up in a conservative country. International Review of Sociology, 23, 3, pp. 542-563. 
Misra, J., Budig, M., \& Boeckmann, I. (2011). Work-family policies and the effects of children on women's employment hours and wages. Community, Work \& Family, 14, 2, pp. 139-157.

Moss, P. (2014). 10 $0^{\text {th }}$ International Review of Leave Policies and Related Research 2014. http://www.leavenetwork.org/lp_and_r_reports/review_2014/ [Retrieved: 2014-12-10].

Neyer, G., \& Andersson, G. (2008). Consequences of family policies on childbearing behavior: Effects or artifacts? Population and Development Review, 34, 4, pp. 699-724.

Ondrich, J., Spiess, C. K., Yang, Q., \& Wagner, G. G. (2003). The liberalization of maternity leave policy and the return to work after childbirth in Germany. Review of Economics of the Household, 1, 12, pp. 77-110.

Pettit, B., \& Hook, J. (2005). The structure of women's employment in comparative perspective. Social Forces, 84, 2, pp. 779-801.

Pfau-Effinger, B. (2001). Wandel wohlfahrtstaatlicher Geschlechterpolitiken im sozio-kulturellen Kontext. In: Heintz, B. (Ed.), Geschlechtersoziologie. Wiesbaden: Westdeutscher Verlag, pp. 487-511.

Pfau-Effinger, B. (2004). Socio-historical paths of the male breadwinner model - An explanation of cross-national differences. The British Journal of Sociology, 55, 3, pp. 377-399.

Pronzato, C. (2009). Return to work after childbirth: does parental leave matter in Europe? Review of Economics of the Household, 7, 4, pp. 341-360.

Puhani, P. A., \& Sonderhof, K. (2011). The effects of parental leave extension on training for young women. Journal of Population Economics, 24, 2, pp. 731-760.

Pull, K., \& Vogt, A.-C. (2010). Much ado about nothing? The effects of the German parental leave reform. Soziale Welt, 61, 2, pp. 121-137.

Rege, M.and I.F. Solli. (2013). The impact of paternity leave on fathers' future earnings. Demography, 50, pp. 2255-2277.

Ronsen, M., \& Sundstrom, M. (2002). Family policy and after-birth employment among new mothers - A comparison of Finland, Norway and Sweden. European Journal of Population, 18, 2, pp. 121-152.

Ruhm, C. J. (1998). The economic consequences of parental leave mandates: Lessons from Europe. Quarterly Journal of Economics, 113, 1, pp. 285-317.

Schober, P. S. (2014). Parental leave, maternal and paternal domestic work: A longitudinal study of two reforms in West Germany. Journal of Social Policy, 43, 2, pp. 351-372.

Sullivan, O., Coltrane, S., Mcannally, L., \& Altintas, E. (2009). Father-friendly policies and time-use data in a cross-national context: potential and prospects for future research. Annals of the American Academy of Political and Social Science, 624, pp. 234-254.

Steiber, N., \& Haas, B. (2012). Advances in explaining women's employment patterns. Socio-Economic Review, 10, 2, pp. 343-367.

Trappe, H. (2013). Väterzeit -Das Elterngeld als Beschleuniger von Gleichstellung? Zeitschrift für Familienforschung/Journal of Family Research, 25, 2, pp. 238-264.

Submitted on/Eingereicht am: 21.07.2015

Accepted on/Angenommen am 04.02.2016

Address of the author/Anschrift der Autorin:

$\operatorname{Dr}^{\text {in }}$ Helene Dearing

WU Vienna University of Economics and Business

Institute for Social Policy

Welthandelsplatz 1

1020 Vienna

Austria/Österreich

Email: helene.dearing@wu.ac.at 


\section{Appendix}

Table 1: Parental leave policies in European countries

\begin{tabular}{|c|c|c|c|c|c|c|}
\hline \multirow[t]{2}{*}{ Country } & \multicolumn{2}{|c|}{ Maternity Leave (in months) } & \multicolumn{2}{|c|}{ Paternity Leave (in weeks) } & \multicolumn{2}{|c|}{ Parental Leave (in months) } \\
\hline & Total & Paid & Total & Paid & Total & Paid \\
\hline Austria & 1.9 & 1.9 & 0 & 0 & 24.0 & 24.0 \\
\hline Belgium & 3.3 & 3.3 & 2 & 2 & 8.0 & 8.0 \\
\hline Croatia & 6.0 & 6.0 & 0 & 0 & 8.0 & 8.0 \\
\hline Czech Rep. & 5.1 & 5.1 & 0 & 0 & 36.0 & 36.0 \\
\hline Denmark & 3.3 & 3.3 & 2 & 2 & 14.9 & 7.4 \\
\hline Estonia & 3.7 & 3.7 & 2 & 2 & 36.0 & 36.0 \\
\hline Finland & 2.9 & 2.9 & 9 & 9 & 6.1 & 6.1 \\
\hline France & 3.3 & 3.3 & 2 & 2 & 36.0 & 36.0 \\
\hline Germany & 1.9 & 1.9 & 0 & 0 & 36.0 & $10.0+2$ \\
\hline Greece & 8.1 & 8.1 & 2 days & 2 days & 8.0 & 0.0 \\
\hline Hungary & 5.6 & 5.6 & 1 & 1 & 36.0 & 36.0 \\
\hline Iceland & 0.0 & 0.0 & 0 & 0 & 9.0 & 9.0 \\
\hline Ireland & 9.3 & 6.0 & 0 & 0 & 8.4 & 0.0 \\
\hline Italy & 3.7 & 3.7 & 1 day & 1 day & $10.0+1$ & $10.0+1$ \\
\hline Lithuania & 1.9 & 1.9 & 4 & 4 & 36.0 & 24.0 \\
\hline Luxembourg & 1.9 & 1.9 & 2 days & 2 days & 12.0 & 12.0 \\
\hline Netherlands & 2.8 & 2.8 & 2 days & 2 days & 12.0 & 12.0 \\
\hline Norway & 0.0 & 0.0 & 2 & 0 & 13.0 & 13.0 \\
\hline Poland & 12.0 & 12.0 & 2 & 2 & 36.0 & 24.0 \\
\hline Portugal & 0.0 & 0.0 & 0 & 0 & $12.0+1$ & $12.0+1$ \\
\hline Slovakia & 6.5 & 6.5 & 0 & 0 & 36.0 & 36.0 \\
\hline Slovenia & 2.6 & 2.6 & 13 & 13 & 8.6 & 8.6 \\
\hline Spain & 4.6 & 4.6 & 2.1 & 2.1 & 36.0 & 0.0 \\
\hline Sweden & 0.0 & 0.0 & 2 & 2 & 36.0 & 15.9 \\
\hline Switzerland & 3.7 & 3.3 & 0 & 0 & 0.0 & 0.0 \\
\hline UK & 12.0 & 9.1 & 2 & 2 & 8.4 & 0.0 \\
\hline
\end{tabular}

Source: Moss (2014: 8ff) 


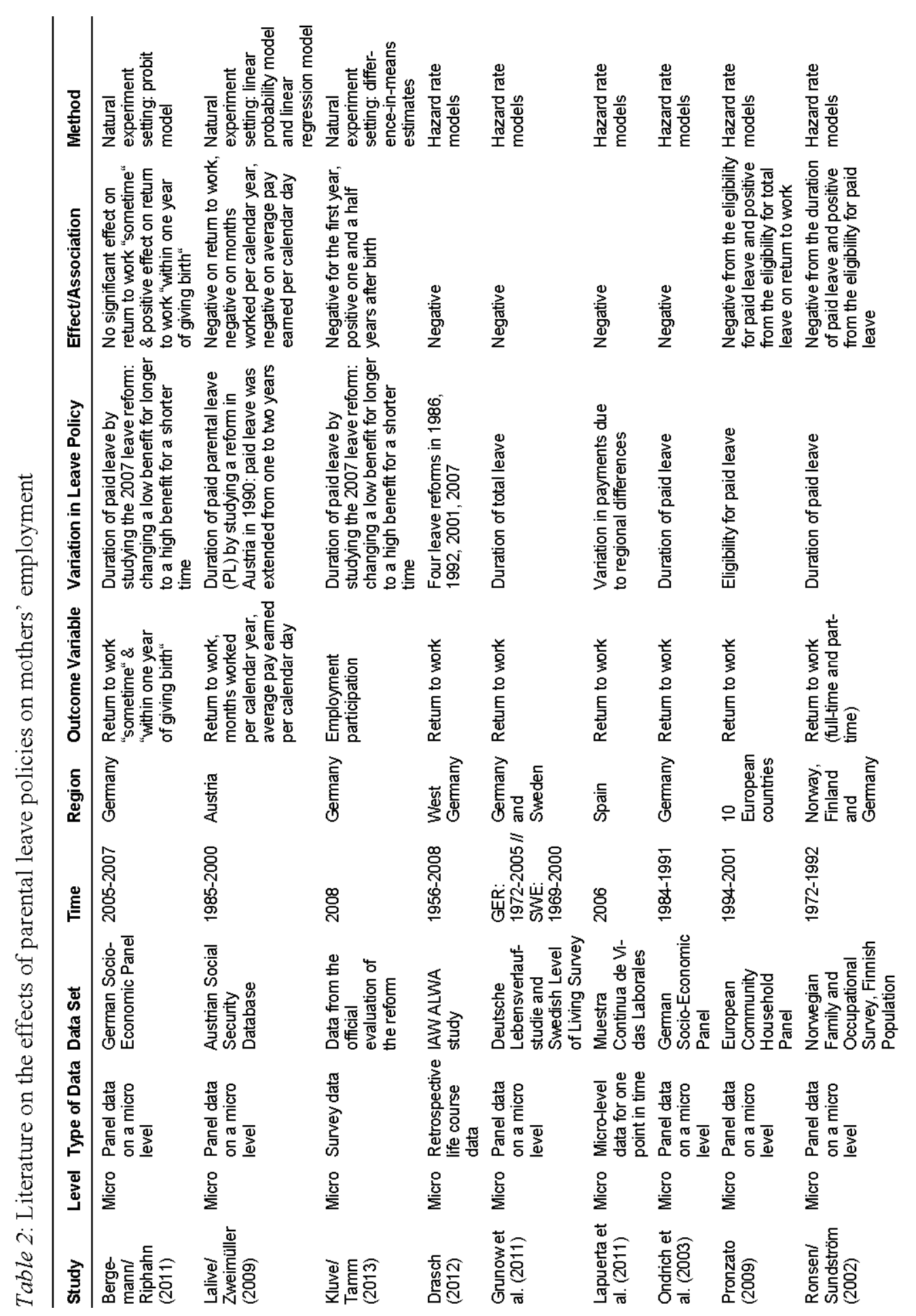




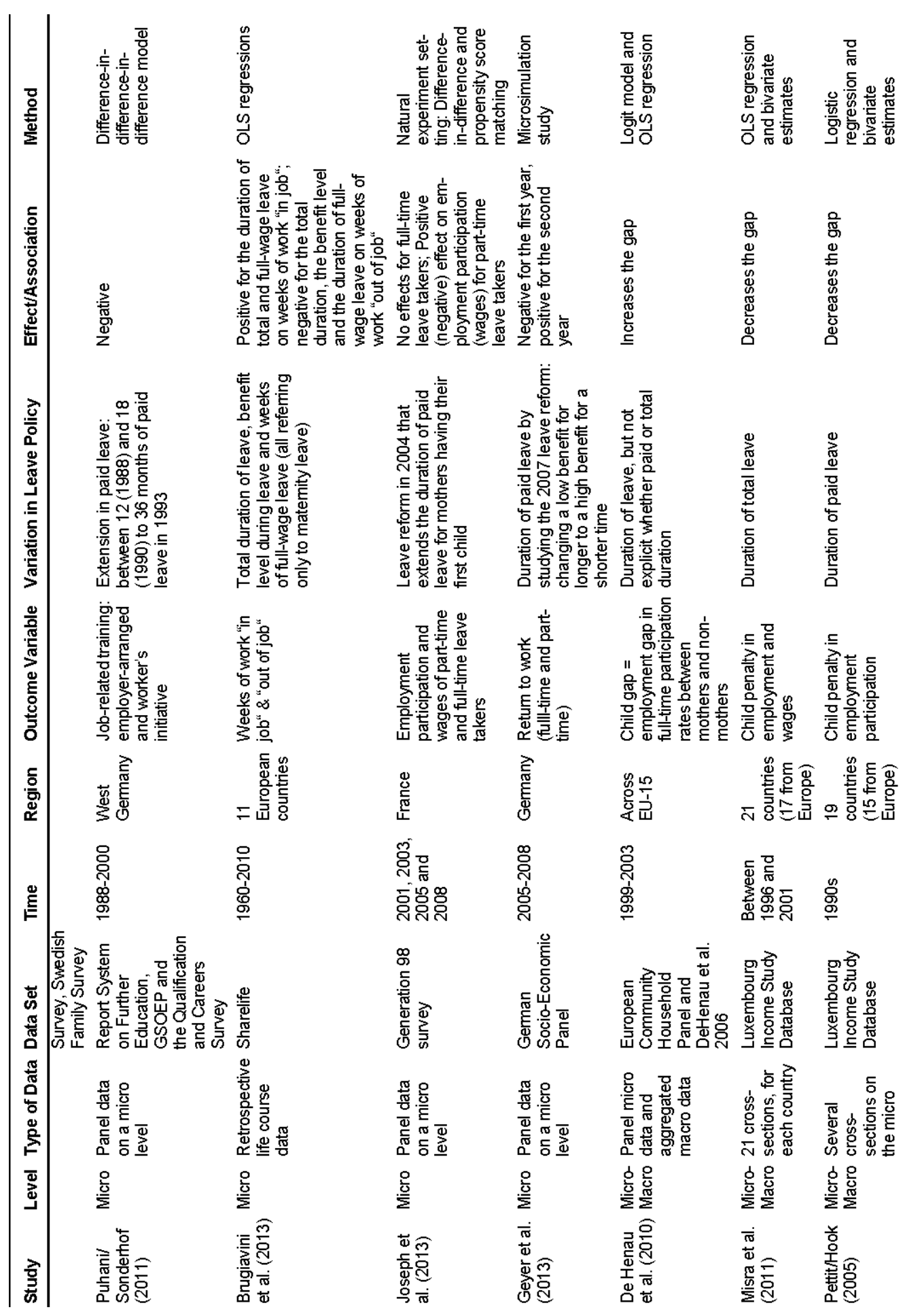




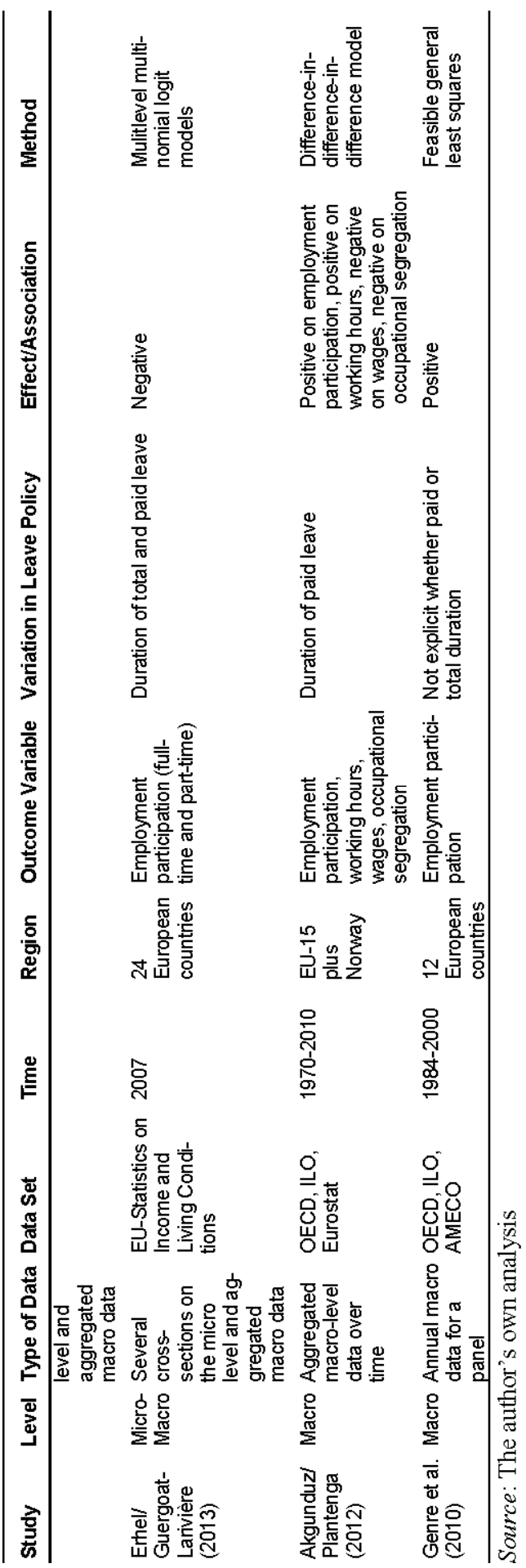




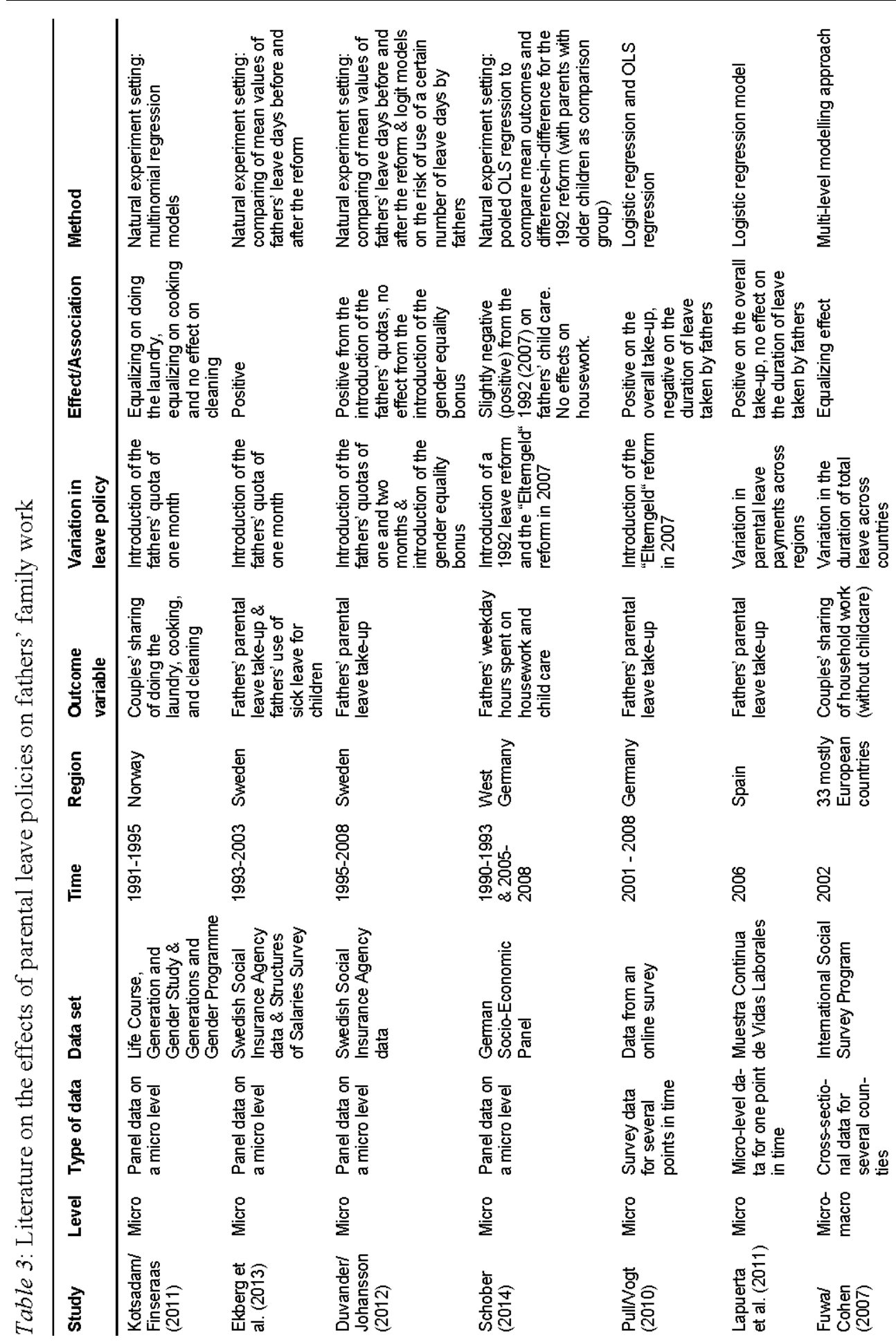




\begin{tabular}{|c|c|c|c|}
\hline 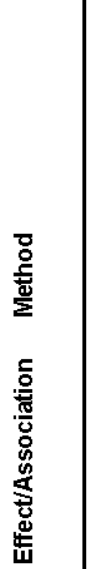 & 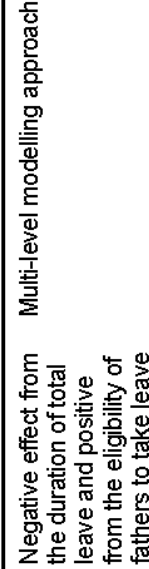 & 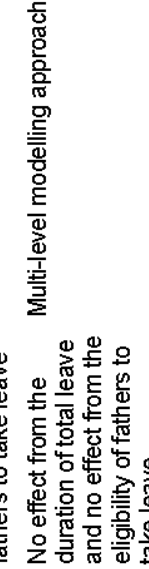 & 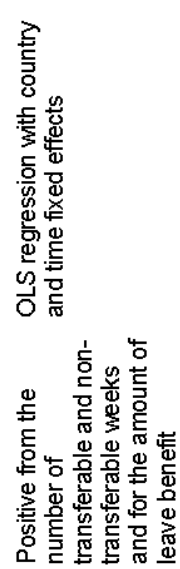 \\
\hline 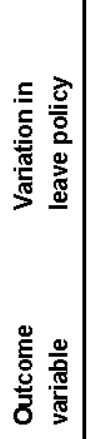 & 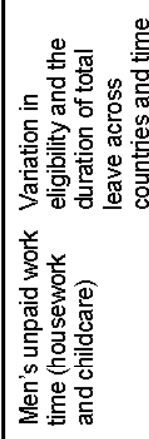 & 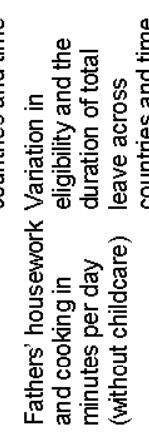 & 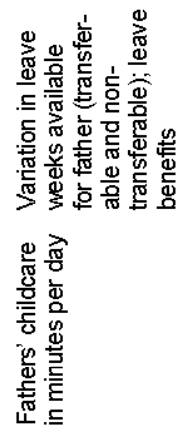 \\
\hline 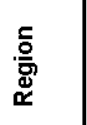 & 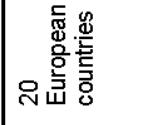 & 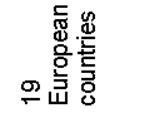 & 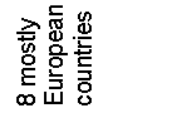 \\
\hline$\stackrel{\stackrel{\mathscr{E}}{E}}{\underline{F}}$ & 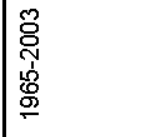 & 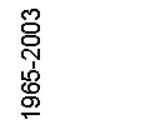 & 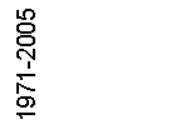 \\
\hline 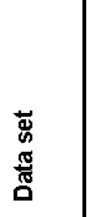 & 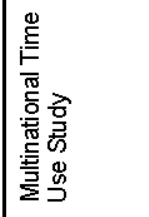 & 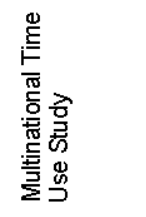 & 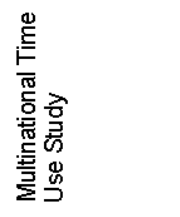 \\
\hline 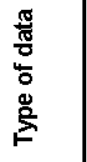 & 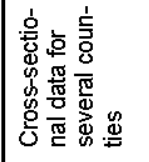 & 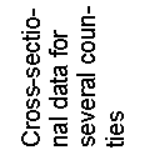 & 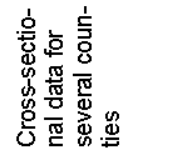 \\
\hline 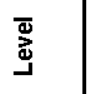 & 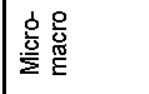 & $\begin{array}{l}\text { 응 } \\
\text { 을 } \\
\text { 总 }\end{array}$ & $\begin{array}{l}\text { do } \\
\text { 을 } \\
\text { 을 }\end{array}$ \\
\hline 离 & 흥웡 & 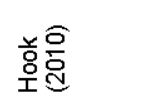 & 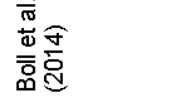 \\
\hline
\end{tabular}




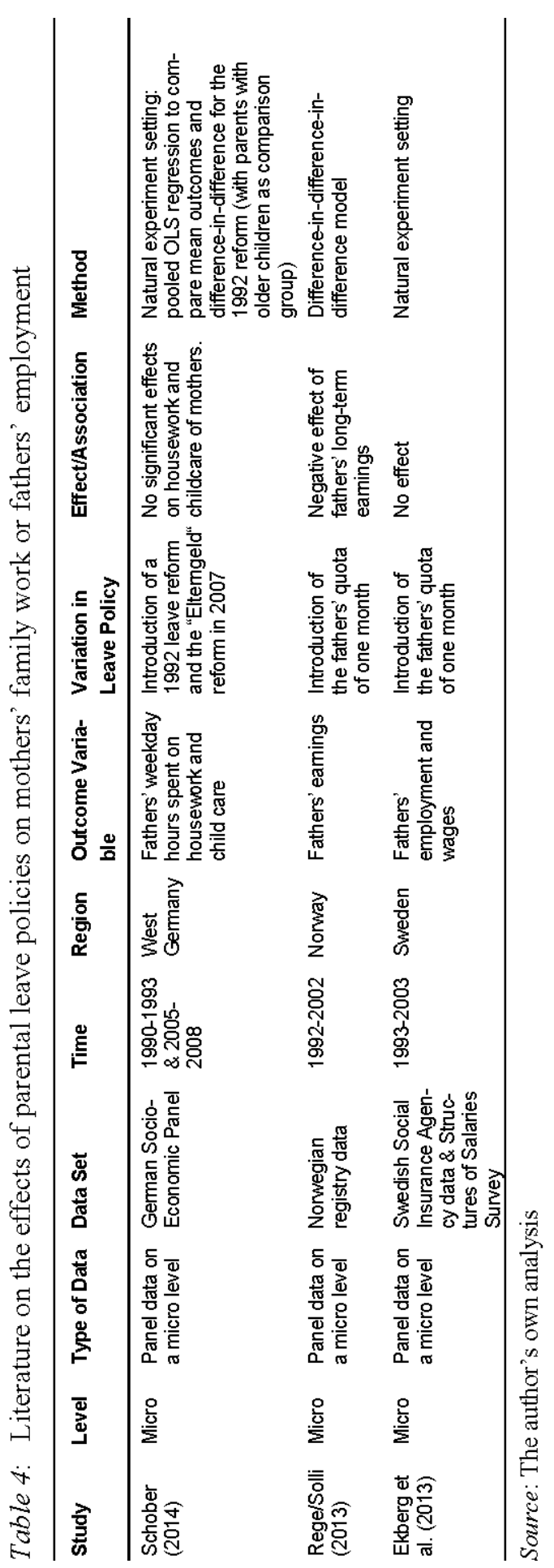

